\title{
Efektivitas pendekatan pendidikan matematika realistik (PMR) dalam meningkatkan hasil belajar penjumlahan pecahan berpenyebut berbeda di sekolah dasar
}

\author{
Fadiah Elwijaya $^{\left.1^{*}\right)}$, Firman Firman ${ }^{2}$, Desyandri Desyandri $^{3}$ \\ ${ }^{123}$ Universitas Negeri Padang
}

\begin{tabular}{l} 
Article Info \\
\hline Article history: \\
Received Jan $28^{\text {th }}, 2021$ \\
Revised Feb $16^{\text {th }}, 2021$ \\
Accepted Feb $21^{\text {st }}, 2021$ \\
\hline
\end{tabular}

\section{Keyword:}

Pendekatan matematika realistik Hasil Belajar

\begin{abstract}
ABSTRAK
Tujuan penelitian ini adalah mendeskripsikan peningkatan hasil belajar penjumlahan pecahan berpenyebut berbeda dengan pendekatan Pendidikan Matematika Realistik (PMR) di Kelas V SDN 19 Paninjauan, Kecamatan X Koto, Kabupaten Tanah Datar. Penelitian ini adalah penelitian tindakan kelas yang terdiri dari II siklus. Subjek pada penelitian ini adalah siswa kelas V SDN 19 Paninjauan yang berjumlah 22 orang. Rata-rata perolehan pada penilaian RPP adalah $85,4 \%$ dengan kriteria sangat baik, siklus II 93,72\% dengan kriteria sangat baik. Aspek guru pada siklus I memperoleh rata-rata 81,25\% dengan kriteria sangat baik dan siklus II diperoleh 89,09\% dengan kriteria sangat baik. Pada siklus I perolehan hasil belajar dengan rata-rata 52,23\% dengan kriteria kurang dan pada siklus II 77,15\% kriteria baik. Sehingga dapat disimpulkan bahwa Pendekatan PMR dapat meningkatkan hasil belajar penjumlahan pecahan berpenyebut berbeda di Kelas V SDN 19 Paninjauan.
\end{abstract}

(C) 2021 The Authors. Published by IICET.

This is an open access article under the CC BY-NC-SA license

(https://creativecommons.org/licenses/by-nc-sa/4.0

\section{Corresponding Author:}

Fadiah Elwijaya,

Universitas Negeri Padang

Email: fadiah_elwijaya@yahoo.com

\section{Pendahuluan}

Pembelajaran pecahan merupakan salah satu materi dalam pembelajaran matematika yang harus diajarkan pada tingkat satuan pendidikan Sekolah Dasar (SD).Pecahan diajarkan mulai dari kelas III sampai kelas VI dengan Kompetensi Dasar (KD) yang berbeda. Salah satu pembelajaran pecahan yang dipelajari oleh siswa kelas V SD adalah operasi penjumlahan pecahan berpenyebut tidak sama pada KD 3.1 Menjelaskan dan melakukan penjumlahan dan penjumlahan dua pecahan dengan penyebut berbeda.

Gravemeijer (dalam ((Hadi, 2018)) mengemukakan bahwa penjumlahan pecahan dengan penyebut berbeda sebaiknya bermakna bagi siswa siswa mudah dalam mengaplikasikan materi penjumlahan pecahan tidak sama pada kehidupan nyata. Guru dalam mengajarkan penjumlahan pecahan berpenyebut tidak sama supaya dapat menggali kembali dan mengkonstruksi ide-ide secara mandiri, maka sebaiknya dapat mengaitkan skemata siswa dapat dikaitkan dengan pembelajaran.

Dari hasil observasi peneliti pada kelas V SDN 19 Paninjauan, Kecamatan X Koto, Kabupaten Tanah Datar pada semester ganjil tahun pelajaran 2018/2019 tentang proses pembelajaran penjumlahan pecahan berpenyebut tidak sama. Maka didapat data bahwa siswa terkendala dalam belajar matematika khususnya pada topik penjumlahan pecahan berpenyebut tidak sama. Guru dalam memulai pembelajaran kurang menggunakan masalah yang realistik atau masalah yang dekat dengan lingkungan siswa, siswa kurang dimotivasi untuk menyelesaikan sendiri permasalahan yang diberikan, dan meminta siswa 
mengkomunikasikan cara penyelesaian masalah dengan teman, serta mengaitkan materi penjumlahan pecahan berpenyebut tidak sama dengan materi pelajaran lain. Guru menyebutkan rumus dan algorutma ke siswa. Padahal guru adalah dasar untuk menentukan kualitas lulusan siswa. Maka sangat dibutuhkan guru yang profesional dalam proses perkembangan pendidikan. (Firman, 2018).

Salah satu pendekatan dalam proses pembelajaran yang menggunakan dunia nyata adalah Pendekatan PMR. Hal ini sesuai dengan salah satu aspek PMR yang dikemukakan oleh De Lange (dalam (Daryanto \& Tasrial, 2012)) bahwa agar siswa terlibat dalam proses pembelajaran yang lebih bermakna bagi siswa, maka sebaiknya pembelajaran diawali dengan pengajuan masalah riil yang sesuai dengan pengalamannya masingmasing. Masalah.kontekstual.ini bermanfaat bagi siswa untuk menemukan hubungan antara masalah riil dengan materi pembelajaran yang sedang dipelajari (Yesya, Desyandri, \& Alwi, 2018) . (Fitriani \& Maulana, 2016) juga mengatakan bahwa kemampuan pemahaman matematis dengan kemampuan pemecahan masalah terdapat hubungan yang positif.

Dalam proses pembelajaran menggunakan pendekatan PMR, siswa diberi kesempatan mengkonstruksi serta menemukan kembali tentang konsep matematika sehingga akhirnya siswa memahami konsep pengertian terhadap materi pembelajaran dengan kuat. Gravemeijer (dalam (Hadi, 2018)) juga mengatakan bahwa dalam pembelajaran orang dewasa harus melakukan bimbingan terhadap siswa agar dapat menggali kembali ide-ide serta konsep matematika. Hal ini bertujuan untuk mengupayakan semua keadaan atau situasi kondisi dan masalah realistik, sehingga proses pembelajaran menjadi bermakna bagi siswa dan dapat menarik minat siswa dalam pembelajaran pecahan sehingga dapat meningkatkan hasil belajar penjumlahan pecahan berpenyebut tidak sama.

Hasil belajar adalah perubahan perilaku pada siswa pada aspek kognitif, afektif, dan psikomotor yang berorientasi terhadap proses pembelajaran (Maisyarah \& Firman, 2019). Sedangkan menurut Nasution (dalam (Kunandar, 2011)) mengatakan bahwa hasil belajar merupakan suatu perubahan terhadap individu yang belajar, yang mencakup pengetahuan, kecakapan, dan penghayatan terhadap siswa tersebut. Jadi, bisa diambil kesimpulan bahwa hasil belajar adalah segala sesuatu yang diperoleh dan dikuasai oleh siswa setelah melaksanakan proses pembelajaran.

Hasil belajar terdiri dari 3 ranah yaitu kognitif, afektif dan psikomotor. Dalam penelitian ini pada ranah kognitif, yang akan penulis ukur adalah jenjang pengetahuan, pemahaman, dan aplikasi. Karena ketiga jenjang tersebut sesuai dengan materi pembelajaran penjumlahan pecahan berpenyebut tidak sama dengan menggunakan pendekatan PMR.pada ranah afektif, yang akan penulis gunakan dalam penelitian adalah jenjangmenerima, menanggapi, dan menghargai. Untuk jenjang menerima yang akan diukur adalah keseriusan siswa dalam melakukan kerja kelompok. Untuk jenjang menanggapi yang akan diukur adalah keaktifan siswa saat berdiskusi. Untuk jenjang menghargai yang akan diukur adalah saling menghargai antar kelompok. Pada psikomotor penulis hanya menggunakan 2 taraf saja yaitu (1) keterampilan menggunakan media untuk mengkur taraf keterampilan gerakan dasar(2) kemampuan menjawab pertanyaan dan kerja sama untuk mengkur taraf keharmonisan dan ketepatan.

Heuvel (dalam (Wijaya \& Ariadi, 2012)) mengemukakan bahwa pendekatan PMR adalah pendekatan pada pelajaran Matematika dari Belanda. Kata "realistik" sering dimaknai dengan "real-world", yakni dunia nyata. Sebagian orang beranggapan bahwa PMR adalah pendekatan dalam pembelajaran matematika yang menggunakan masalah kehidupan sehari-hari. Kata "realistik" berasal dari bahasa Belanda "zich realiseren" yang mempunyai arti "untuk dibayangkan".

Ada lima karateristik PMR menurut Treffers (dalam (Wijaya \& Ariadi, 2012)) yaitu: (a) menggunakan konteks, (b) menggunakan model untuk matematisasi progresif, (c) memanfaatkan hasil konstruksi siswa, (d) kegiatan interaktivitas, dan (e) mengaitkan pembelajaran dengan topik lain.

Berdasarkan pemaparan di atas, rumusan permasalahan penelitian ini adalah: Bagaimanakah Peningkatan Hasil Belajar Penjumlahan Pecahan Berpenyebut berbeda di kelas V SDN 19 Paninjauan?. Dan tujuan penelian yakni untuk mendeskripsikan Peningkatan Hasil Belajar penjumlahan pecahan berpenyebut berbeda di kelas V SDN 19 Paninjauan.

\section{Metode}

Penelitian dilaksanakan di SDN 19 Paninjauan. Karena berdasarkan observasi penulis pada pembelajaran penjumlahan pecahan berpenyebut tidak sama di SDN 19 Paninjauan belum pernah menggunakan pendekatan PMR yang siswanya berjumlah 22 orang, terdiri dari 11 siswa perempuan dan 11 siswa laki-laki. Subjek pada penelitian ini adalah siswa kelas V SDN 19 Paninjauan. 
Penelitian ini dilakukan pada tahun pelajaran 2019-2020 pada semester II di kelas V SDN 19 Paninjauan. Penelitian ini terdiri dari dua siklus, setiap siklus dilaksanakan dalam dua kali pertemuan. Siklus 1 pertemuan 1 dilaksanakan pada hari Senin tanggal 22 Juli 2020 dan pertemuan 2 pada hasri Rabu tanggal 24 Juli 2019. Pertemuan 1 Siklus II dilaksanakan pada hari Senin tanggal 29 Juli 2019 dan pertemuan 2 pada hari Rabu tanggal 31 Juli 2019.

Penelitian ini merupakan Penelitian Tindakan Kelas (PTK). Menurut Lewin (dalam Kunandar, 2011:42) bahwa penelitian tindakan kelas merupakan suatu rangkaian langkah yang terdiri dari empat tahap yakni perencanaan, tindakan, pengamatan dan refleksi". Pendekatan Penelitian yang akan dilakukan menggunakan pendekatan kualitatif dan kuantitatif. Menurut (Arikunto, 2012) mengatakan bahwa pendekatan kualitatif digunakan karena penelitian ini terjadi secara alamiah, apa adanya dan dalam situasi normal dan tidak dimanipilasi keadaan dan kondisinya, menekankan kepada deskripsi secara alamia, dan menuntut keterlibatan peneliti secara langsung".Pendekatan kualitatif merupakan penelitian yang menggunakan data-data berbentuk verbal atau dengan menggunakan kata kerja, dilakukan atau diperaktekkan, selanjutnya penelitian ini juga menggunakan pendekatan kuantitatif adalah pendekatan yang menyajikan data numerik/angka-angka dalam bentuk tabel, grafik dan sebagainya dengan analisis statistik deskriktif (analisis data kuantitatif) diperoleh dari skor akhir tes atau evaluasi yang dilakukan siswa SD yang diteliti. Alur pelaksanaan sesuai dengan pendapat (Arikunto, 2012) merinci tahapan PTK yakni : perencanaan, pelaksanaan, pengamatan, dan refleksi.

Dalam menganalisis data dilaksanakan pada data yang telah direduksi. Analisis data bertujuan untuk menemukan informasi yang lebih rinci dan focus terhadap hal yang yang mendukung dan menghambat proses pembelajaran. Teknik analisis data menggunakan analisis data menurut (Purwanto, 2011) NP adalah nilai persen yang diharapkan, $\mathrm{R}$ adalah skor mentah yang diperoleh, SM adalah skor maksimal ideal dari tes yang bersangkutan, dan 100 adalah konstan.

\section{Hasil dan Pembahasan}

\section{Siklus I Pertemuan 1}

Pembelajaran siklus I pertemuan satu ini dilaksanakan selama tiga jam pembelajaran, terlebih dahulu peneliti mewujudkan pembelajaran penjumlahan pecahan berpenyebut berbeda dengan pendekatan PMR ini ke dalam Rencana Pelaksaaan Pembelajaran (RPP) yang disusun berdasarkan kurikulum 2013 semester I tahun pelajaran 2019/2020. KD 3.1 Menjelaskan dan melakukan penjumlahan dan penjumlahan dua pecahan dengan penyebut berbeda. Untuk mencapai KD ini dituangkan dalam indicator yang mengacu kepada karakteristik pendekatan PMR. Peneliti mempersiapakan lembaran pengamatan untuk mengamati aktifitas guru dan siswa dalam pembelajaran penjumlahan pecahan berpenyebut berbeda dengan pendekatan PMR yang diamati oleh dua orang observer.

Dalam RPP pembelajaran terbagi atas tiga kegiatan yaitu kegiatan awal, kegiatan inti dan kegiatan akhir yang disesuaikan dengan karakteristik PMR yang sesuai dengan kajian teori. Pelaksanaan pembelajaran pada pertemuan I adalah pada hari Senin 22 Juli 2019 (3x 35 menit). Dalam pelaksana terdiri dari kegiatan awal, inti, dan akhir. Pengamatan RPP dilakukan oleh observer, dari hasil pengamatan tersebut RPP memperoleh nilai 83,3\%. pada aktivitas guru memperoleh nilai $75 \%$ dengan taraf keberhasilan kualifikasi cukup. Pada aktivitas siswa memperoleh nilai $62,5 \%$ dengan kualifikasi kurang.

Hasil belajar kognitif siswa 10 orang yang memenuhi atau melebihi Kriteria Ketuntasan Minimum (KKM) sedangkan 12 orang tidak memnuhi KKM. Dengan rata-rata ketuntasan belajar 45,45\% sedangkan ketuntasan yang diharapkan $70 \%$. Untuk penilaian afektif siswa dengan rata-rata $71,6 \%$ dan penilaian psikomotor 72,3\%. Beradasarkan hasil pengamatan hasil belajar siswa belum memenuhi ketuntasan belajar yang diharapkan. Untuk itu diadakan perbaikan pada pertemuan dua. Secara keseluruhan hasil belajar siswa pada siklus ini belum mencapai target keberhasilan yang diharapkan, sehingga perlu perbaikan dan dilanjutkan pada pertemuan selanjutnya.

\section{Siklus 1 Pertemuan 2}

Pada pertemuan kedua ini tidak jauh berbeda dengan pertemuan pertama pada pertemuan dua ini yaitu siswa melaksanakan pembelajaran penjumlahan pecahan berpenyebut berbeda dengan pendekatan PMR.Sama halnya dengan pertemuan satu penelitian ini juga dirancang lebih awal dengan RPP yang terdapat karakteristik PMR dalam komponen RPP yang tertuang dalam tiga jenis kegiatan yaitu kegiatan awal, inti dan akhir.

Pelaksaan pertemuan kedua ini adalah 24 Juli 2019 yang dilakukan 3 x 35 menit yang dimulai pada puluk 10.30-12.15. Pembelajaran dmasih dihadiri oleh 22 orang siswa. Kegiatan awal mengkondisikan kelas dan membangkitkan skemata siswa terkait penjumlahan pecahan dengan memberikan pertanyaan secara tanya 
jawab pada siswa. Pada kegiatan inti siswa melakukan pembelajaran dengan pendekatan PMR dengan menyelesaikan permasalahan realistic terkait penjumlahan pecahan.Kerja kelompok tertuang pada LKS yang disedia oleh guru.Sedangkan kegiatan akhir adalah penyimpulan pembelajaran antara siswa dan guru yang dipancing oleh pertanyaan dan diakhiri dengan pemberian tes kognitif pada siswa.

Pengamatan yang dilakukan terhadap RPP mengalami peningkatan menjadi 87,5 dengan taraf keberhasilan kualifikasi baik. Sedangkan persentase yang diperoleh dari penilaian pengamatan terhadap aktifitas guru adalah 87,5 dengan kualifikasi baik dan aspek siswa 78,12 dengan kualifikasi cukup. Rata-rata hasil belajar yang diperoleh siswa pada pembelajaran adalah 67,9 dengan ketuntasan belajar 59\%. Sedangkan aspek afektif 77,18\% dengan kualifikasi cukup dan $76 \%$ untuk aspek psikomotor siswa.

Berdasarkan hasil pengamatan penelitian pada siklus I belum berhasil sehingga penelitian ini dilanjutkan pada siklus II, dengan lebih memperhatikan kekurangan pada 1) lebih teliti dalam kelengkapan RPP, 2) mampu memotivasi siswa dalam menyelesaikan masalah dalam kelompok, 3) Guru memberikan dedukasi saat siswa mengerjakan evaluasi agar lebih serius, 4) memperhatikan kendala dan kekurangan dalam siswa bekerja kelompok.

\section{Siklus II Pertemuan 1}

Pada siklus I penelitian dianggap belum berhasil, hal ini dikarenakan masih ada kelemahan atau kekurangan dari pengamatan siklus I. Oleh karena itu, penelitian ini dilanjutkan pada siklus II. Pada siklus II peneliti menyusun RPP , LKS, tes evaluasi, dan lembaran pengamatan untuk pengamatan proses pembelajaran berupa lembar observasi aspek guru dan siswa.

Pelaksanaan pada pertemuan pertama siklus II ini dilakukan pada tanggal 29 Juli 2019.Pada pukul 07.4509.30 (3x 35 menit) dengan jumlah siswa 22 orang.Kegiatan pmbelajaran dalam tiga kegiatan yaitu kegiatan awal, kegiatan inti, kegiatan akhir yang mana di dalam kegiatan ini terdapat tahapan metode eksperimen dan guru melakukan eksplorasi, elaborasi dan konfirmasi bersama siswa.

Berdasarkan pengamatan nilai pengamatan untuk RPP pada pertemuan ini adalah91,6\% dengan taraf keberhasilan pada kualifikasi sangat baik. Hal ini menunjukan peningkatan karena peneliti berpedoman pada kekurangan yang terdapat di siklus I dan berkolaborasi dengan kedua observer.

Pengamatan untuk aktifitas guru yang dilakukan oleh observer adalah $87,5 \%$ hal ini menunjukan kualifikasi baik. Sedangkan aktifitas siswa memperoleh nilai pengamatan $81,25 \%$ ini menunjukan taraf keberhasilan dengan kualifikasi baik. Sementara itu untuk hasil belajar siswa dilakukan penilaian hasil yaitu aspek kognitif dan penilaian proses yaitu aspek afektif dan psikomotor. Dari 22 orang siswa masih ada 7 orang siswa yang belum tuntas sehingga persentase ketuntasan siswa baru mencapai 68\% dengan rata-rata nilai perorangan 69,9\%. Keberhasilan siswa dari aspek afektif yaitu 79\% dengan kualifikasi cukup dan aspek psikomotor $80 \%$ dengan taraf keberhasilan kualifikasi baik.

\section{Siklus II Pertemuan 2}

Siklus II pertemuan dua dilanjutkan pada tanggal 31 Juli 2019 masih dengan pendekatan PMR yang sama materi dilanjutkan masih tentang penjumlahan pecahan berpenyebut berbeda. Nilai pengamatan terhadap RPP peneliti yaitu 95,83\% hal ini menujukan rencana pembelajaran peneliti telah mencapai kualifikasi sangat baik, peneliti telah melakukan perbaikan dari pertemuan sebelumnya. Sedangkan untuk kegiiatan pembelajaran dari segi aktifitas guru memperoleh nilai pengamatan 90,67 hal ini menujukan kualifikasi sangat baik. Begitu juga pada aktifitas siswa dengan nilai pengamatan 90,67\% dengan kualifikasi sangat baik.

Keberhasilan siswa pada pertemuan ini dinilai dari tiga aspek yaitu kognitif siswa sebagai penilaian hasil yaitu dengan ketuntasan belajar $86,3 \%$ hal ini menujukan ketuntasan sudah melebihi yang diharapkan. Pada aspek afektif keberhasilan siswa sudah mencapai 84,09\% (baik) dan psikomotor siswa 84,45 \% (baik).

Perencanaan tindakan pembelajaran terlebih dahulu telah dirancang rancangan pembelajaran dalam benruk RPP. (Muslich, 2012) mengatakan bahwa " RPP merupakan rancangan proses yang oleh guru dalam proses pembelajaran. RPP merupakan rencana operasional pembelajaran yang memuat Standar Komperetnsi (SK), Kompetensi Dasar (KD) dan beberapa Indikator, yang pencapaiannya dituangkan dalam beberapa tujuan pembelajaran, materi pembelajaran, metode yang akan digunakan, langkah-langkah kegiatan pembelajaran, serta alat sumber dan bahan yang digunakan dan penilaian kepada siswa. Berdasarkan pengmatan dan penilaian RPP I ini sudah berada dalam taraf keberhasilan kualifikasi baik namun masih terdapat kekurangan pada kejelasanan rumusan tujuan pembelajaran pda descriptor tujuan pembelajaran belum memenuhi ( $\mathrm{A}=$ audience, $\mathrm{B}=$ behavior, $\mathrm{C}=$ condition, $\mathrm{D}=$ degree $)$. Deskriptor ini harus terlihat jelas dalam tujuan pembelajaran sehingga indicator yang ingin dicapai dapat terarah. Dan pedoman penskoran belum terpenuhi ini sangat perlu dituliskan dan disampaikan pada siswa sehingga siswa tidak bermain-atau 
tidak serius dalam mengerjakan evaluasi dan untuk membantu penilai lain jika seandainya ada hambatan guru untuk menilai.

Pelaksanaan pembelajaran penjumla-han pecahan berpenyebut berbeda dengan pendekatan PMR ini sesuai dengan yang dikemukan oleh Rostiyah. Langkah pembelajaran terdiri dari kegiatan awal yang terurai atas mengkondisikan kelas oleh guru dan menyampaikan tujuan pembelajaran Kegiatan inti dibuat secara runtut sesuai dengan langkah eksperimen yang akan digunakan yang mana ini mencerminkan keterlibatan siswa dalam melakukan eksperimen mulai dengan menjelaskan tujuan eksperimen oleh guru, mendiskusikan alat dan bahan yang akan digunakan dalam eksperimen, melaksanakan eksperimen, guru memeberikan pengwasan dan bimbingan, pada siklus I ini guru masih terlihat belum sempurna dalam menyampaikan pembelajaran dikarena guru pertama kali dalam menggunakan PMR ini. Sementara siswa sudah mulai terlibat dan bekerja sendiri dalam menemikan pengalamannya untuk menguji kebenaran teori namun tidak semua siswa terlibat karena siswa asyik melihat kamera.Saat mengerjakan evaluasi siswa terlihat tidak serius belum membaca dan memahami soal dengan baik, terlihat dari sswa banyak bertanya dan ada siswa yang terlalu cepat menjawab tanpa membaca dengan baik.

Hasil belajar siswa masih dalam kategori rendah belum mencapai ketuntasan belajar yang ingin dicapai peneliti ini ditunjukan dengan rata-rata penilaian kognitif 65,31 , afektif $74,3 \%$ dan psikomotor $74,2 \%$. Berdasarkan paparan dan hasil penelitian maka siklus I ini dikatakan belum berhasil dan dilanjutkan ke siklus II dengan memberikan perbaikan pada siklus II.

Pada siklus II metode RPP yang digunakan sudah mengalami peningkatan dan sesuai dengan karakteristik pendekatan PMR namun pelaksanaannya masih kurang sempurna. Siswa sudah terlibat aktif dan bekerja sama, siswa mampu membagi kerja dalam kelompok sehingga mewujudkan kerjasama yang baik, guru telah melakukan eksplorasi terhadap siswa terkait pemahamannya tentang penjumlahan pecahan berpenyebut berbeda, hal ini dipancing oleh guru menggunakan media gambar serta tumbuhan pacar air yang sudah dikenal siswa dan Tanya jawab.

Berdasarkan paparan proses pembelajaran pada siklus II ini sudah berhasil. Dibuktikan oleh hasil pengamatan aktifitas guru dengan rata-rata 89,08\% dan siswa 85,96\% ini menunjukan taraf keberhasilan dengan kualifikasi baik. Begitu juga ketuntasan belajara siswa sudah meningkat yaitu dengan ketuntasan $86,3 \%$ dan aspek afektif $81,50 \%$ dan psikomotor $82,22 \%$ dengan kualifikasi baik.

\section{Simpulan}

Rencana Pelaksanaan Pembelajaran (RPP) dengan pendekatan PMR tidak jauh berbeda dengan RPP yang diterapkan oleh kurikulum dan sekolah. Hanya saja dengan pendekatan PMR disesuaikan dengan karakteristik pendekatan PMR dan pelaksanaan pembelajaran pendekatan PMR pada pembelajaran penjumlahan pecahan berpenyebut berbeda di kelas V SDN 19 Paninjauan sudah terlaksana sesuai dengan langkah metode eksperimen. Pelaksanaannya dilaksanakan dua siklus, dimana siklus I belum terlaksana dengan maksimal dan dilanjutkan pada siklus II. Pada siklus II pembelajaran dengan pendekatan PMR telah terlaksana dengan baik siswa sudah aktif dan mau terlibat dalam dalam menyelesaiakan masalah realistik.Berdasarkan hasil tes terbukti bahwa terjadi peningkatan hasil belajar pecahan dengan pendekatan PMR di kelas V SDN 19 Paninjauan yaitu dengan rata-rata ketuntasan 52,2\%. Sedangkan pada siklus II menjadi $68 \%$ pada pertemuan satu dan $86,3 \%$ pertemuan dua dengan rata-rata $77,15 \%$.

\section{Referensi}

Arikunto, S. (2012). Penelitian Tindakan Kelas. Jakarta: Bumi Aksara.

Daryanto, \& Tasrial. (2012). Konsep Pembelajaran Kreatif. Yogyakarta: Gava Media.

Firman, F. (2018). Efektivitas Bimbingan Kelompok Menggunakan Permainan Simulasi Dalam Meningkatkan Kohesi Sosial, 1-6. https://doi.org/10.31227/osf.io/b6wg8

Fitriani, K., \& Maulana, -. (2016). Meningkatkan Kemampuan Pemahaman Dan Pemecahan Masalah Matematis Siswa Sd Kelas V Melalui Pendekatan Matematika Realistik. Mimbar Sekolah Dasar, 3(1), 4052. https://doi.org/10.17509/mimbar-sd.v3i1.2355

Hadi, S. (2018). Matematika Realistik dan Implementasinya. Banjarmasin: Tulip Banjarmasin.

Kunandar. (2011). Langkah Mudah Penelitian Tindakan Kelas sebagai Pengembangan Profesi Guru. Jakarta: PT Raja Grafindo Persada.

Maisyarah, E., \& Firman, F. (2019). Media Permainan Ular Tangga, Motivasi Dan Hasil Belajar Peserta Didik Di Sekolah Dasar, (January). https://doi.org/10.31227/osf.io/46prn

Muslich, M. (2012). Pembelajaran Berbasis Kompetensi dan Kontekstual. Jakarta: Bumi Aksara. 
Purwanto, N. (2011). Prinsip-Prinsip dan Teknik Evaluasi Pengajaran. Bandung: PT Remaja Rosdakarya.

Sudjana, N. (2011). PenilaianHasil Proses BelajarMengajar. Bandung: PT Remaja Rosdakarya.

Taufik, T., \& Muhammadi. (2011). Mozaik Pembelajaran Inovatif. Padang: SUKABINA Press.

Wijaya, A., \& Ariadi. (2012). Pendidikan Matematika Realistik, Suatu Alternatif Pendekatan Pembelajaran Matematika. Yogyakarta: Graha Ilmu.

Yesya, D. P., Desyandri, \& Alwi, E. (2018). Pengaruh Penggunaan Model Contextual Teaching and Learning (CTL) dalam Pembelajarn PKn di Sekolah Dasar. Inovasi Pembelajaran SD, 6(1), 1-10. 